\title{
Physicochemical and Spectroscopic Characterization of Biofield Treated Triphenyl Phosphate
}

\author{
Mahendra Kumar Trivedi ${ }^{1}$, Alice Branton ${ }^{1}$, Dahryn Trivedi ${ }^{1}$, Gopal Nayak ${ }^{1}$, Khemraj Bairwa ${ }^{2}$, \\ Snehasis Jana ${ }^{2, *}$ \\ ${ }^{1}$ Trivedi Global Inc., Henderson, USA \\ ${ }^{2}$ Trivedi Science Research Laboratory Pvt. Ltd., Bhopal, India
}

Email address:

publication@trivedisrl.com (S. Jana)

To cite this article:

Mahendra Kumar Trivedi, Alice Branton, Dahryn Trivedi, Gopal Nayak, Khemraj Bairwa, Snehasis Jana. Physicochemical and Spectroscopic Characterization of Biofield Treated Triphenyl Phosphate. American Journal of Applied Chemistry.

Vol. 3, No. 5, 2015, pp. 168-173. doi: 10.11648/j.ajac.20150305.13

\begin{abstract}
Triphenyl phosphate (TPP) is a triester of phosphoric acid and phenol. It is commonly used as a fire-retarding agent and plasticizer for nitrocellulose and cellulose acetate. The present study was an attempt to evaluate the impact of biofield treatment on physicochemical and spectroscopic properties of TPP. The study was carried out in two groups i.e. control and treatment. The treatment group was subjected to Mr. Trivedi's biofield treatment. The control and treated samples of TPP were characterized using X-ray diffraction (XRD), differential scanning calorimetry (DSC), thermogravimetric analysis (TGA), Fourier transform infrared (FT-IR), and ultraviolet-visible (UV-Vis) spectroscopy. XRD study revealed the decrease in crystallite size $(6.13 \%)$ of treated TPP that might be due to presence of strains and increase in atomic displacement from their ideal lattice positions as compared to control sample. DSC thermogram of treated TPP showed the increase in melting temperature $(1.5 \%)$ and latent heat of fusion $(66.34 \%)$ with respect to control. TGA analysis showed the loss in weight by $66.79 \%$ in control and $47.96 \%$ in treated sample. This reduction in percent weight loss suggests the increase of thermal stability in treated sample as compared to control. FT-IR and UV spectroscopic results did not show the alteration in the wavenumber and wavelength of FT-IR and UV spectra, respectively in treated TPP with respect to control. Altogether, the $\mathrm{XRD}$ and DSC/TGA results suggest that biofield treatment has the impact on physical and thermal properties of treated TPP.
\end{abstract}

Keywords: Triphenyl Phosphate, Biofield Treatment, X-ray Diffraction, Differential Scanning Calorimetry, Thermogravimetric Analysis

\section{Introduction}

Organophosphorus compounds are comprising carbonphosphorus bonds. These are mainly used for pest control as an alternative to chlorinated hydrocarbons that persist in the environment [1]. Phosphate esters are the groups of organophosphorus compounds with the general structure $\mathrm{P}(=\mathrm{O}) \quad(\mathrm{OR})_{3}$. Triphenyl phosphate is the triester of phosphoric acid and phenol, which is mainly used as the flame retardant agents and plasticizers [2]. Recently, TPP reported as an electrolyte additive to improve the electrochemical performance and thermal safety of lithiumion cells. The conventional lithium-ion batteries have the major issues of safety concerns in the practical application. The TPP is reported to be stable at potentials up to $4.9 \mathrm{~V}$ (vs. $\left.\mathrm{Li} / \mathrm{Li}^{+}\right)$, therefore electrolyte containing TPP had enhanced thermal stability [3]. As evidenced from the literature, the thermal properties of TPP are crucial for its applications as flame retardant agent [4]. Hence, it is advantageous to find out an alternate approach that can improve the thermal stability and other physicochemical properties of TPP in order to get the more useful product. Recently, biofield treatment was reported to alter the physicochemical properties of several metals $[5,6]$ and ceramics $[7,8]$ and spectroscopic properties of various pharmaceutical drugs like paracetamol, piroxicam, chloramphenicol and tetracycline. $[9,10]$.

German scientist George Christopher Lichtenberg coined the term Bioelectrography in 1770 and reported that light coming out from different subjects in electrical fields [11]. It is well known that moving atoms in translation, rotation or vibration state produces the electromagnetic radiation, which 
is also evident from acoustic and vibrational spectroscopy [12]. Similarly, the cells present in human body are also consist with electrons, protons, neutrons and other fundamental particles that are always in vibratory motion. As a result, the bioenergetic field emitted, which surround the human body [13]. In addition, human body used psychological and emotional energies in the form of electrical impulses that also generates the bioenergetic fields to outside the human body [14]. A human has the ability to harness the energy from the environment or Universe and transmit this energy into any object (living or nonliving) on the Globe. The object(s) receive the energy and respond into useful way, this process is termed as biofield treatment. Mr. Trivedi's unique biofield energy treatment is also known as The Trivedi Effect ${ }^{\circledR}$. Recently, the biofield treatment is evaluated in several field like material science [5-8], agricultural science [15, 16], biotechnology [17], and microbiology [18-20].

Conceiving the impact of biofield treatment on various living and nonliving things, the study aimed to evaluate the impact of biofield treatment on physicochemical and spectroscopic properties of TPP using various analytical techniques.

\section{Materials and Methods}

\subsection{Study Design}

Triphenyl phosphate was procured from S D Fine-Chem Limited, India. The study was carried out in two groups i.e. control and treatment. The control sample was remained as untreated; and treatment sample was handed over in sealed pack to Mr. Trivedi for biofield treatment under laboratory conditions. Mr. Trivedi provided the biofield treatment through his energy transmission process to the treatment group without touching the sample. The control and treated samples of TPP were evaluated using various analytical techniques like X-ray diffraction (XRD), differential scanning calorimetry (DSC), thermogravimetric analysis (TGA), Fourier transform infrared (FT-IR), and ultravioletvisible (UV-Vis) spectroscopy.

\subsection{X-ray Diffraction (XRD) Study}

XRD analysis of TPP was accomplished on Phillips, Holland PW 1710 X-ray diffractometer with copper anode and nickel filter. X-ray wavelength used in XRD system was $1.54056 \AA$. The XRD data were obtained in the form of a chart of $2 \theta v s$. intensity. The crystallite size $(\mathrm{G})$ of TPP was calculated using the following equation [21].

$\mathrm{G}=\mathrm{k} \lambda /(\mathrm{b} \operatorname{Cos} \theta)$

Percent change in crystallite size $=\left[\left(\mathrm{G}_{\mathrm{t}}-\mathrm{G}_{\mathrm{c}}\right) / \mathrm{G}_{\mathrm{c}}\right] \times 100$

Where, $\mathrm{G}_{\mathrm{c}}$ and $\mathrm{G}_{\mathrm{t}}$ are crystallite size of control and treated powder samples respectively.

\subsection{Differential Scanning Calorimetry (DSC) Study}

The control and treated samples of TPP were studied using a Pyris-6 Perkin Elmer differential scanning calorimeter
(DSC) on a heating rate of $10^{\circ} \mathrm{C} / \mathrm{min}$ under air atmosphere with air flow rate of $5 \mathrm{~mL} / \mathrm{min}$. An empty pan sealed with cover pan was used as a reference pan. The melting temperature $\left(\mathrm{T}_{\mathrm{m}}\right)$ and latent heat of fusion $(\Delta \mathrm{H})$ were acquired from the DSC curve.

\subsection{Thermogravimetric Analysis-Differential Thermal Analysis (TGA-DTA)}

Thermal stability of control and treated TPP were studied using Mettler Toledo simultaneous TGA and differential thermal analyzer (DTA). The samples were heated up to $400^{\circ} \mathrm{C}$ from room temperature at a heating rate of $5^{\circ} \mathrm{C} / \mathrm{min}$ under air atmosphere. Percent change in temperature at which maximum weight loss occur in sample was calculated from DTG thermogram.

\subsection{Spectroscopic Studies}

For determination of FT-IR and UV-Vis spectroscopic characteristics, the treated sample was divided into two groups i.e. T1 and T2. Both treated groups were analyzed for their spectroscopic characteristics using FT-IR and UV-Vis spectroscopy as compared to control TPP sample.

\subsubsection{FT-IR Spectroscopic Characterization}

FT-IR spectra of control and treated samples of TPP were recorded on Shimadzu's Fourier transform infrared spectrometer (Japan) with frequency range of 4000-500 $\mathrm{cm}^{-1}$. The analysis was accomplished to evaluate the effect of biofield treatment at atomic level like dipole moment, force constant and bond strength in chemical structure [22].

\subsubsection{UV-Vis Spectroscopic Analysis}

UV spectra of control and treated samples of TPP were obtained from Shimadzu UV-2400 PC series spectrophotometer. A quartz cell with $1 \mathrm{~cm}$ and a slit width of $2.0 \mathrm{~nm}$ were used for analysis. The study was carried out using wavelength in the range of 200-400 $\mathrm{nm}$. The UV spectra were analyzed to determine the effect of biofield treatment on the energy gap of highest occupied molecular orbital and lowest unoccupied molecular orbital (HOMOLUMO gap) [22].

\section{Results and Discussion}

\subsection{XRD Analysis}

XRD diffractograms of control and treated TPP are presented in Figure 1. The control TPP showed the XRD peaks at $2 \theta$ equal to $10.72^{\circ}, 13.28^{\circ}, 15.91^{\circ}, 16.03^{\circ}, 16.24^{\circ}$, $18.49^{\circ}, 18.63^{\circ}, 20.18^{\circ}, 21.57^{\circ}$, and $21.75^{\circ}$. However, the XRD diffractogram of treated TPP showed the XRD peaks at $2 \theta$ equal to $10.69^{\circ}, 13.19^{\circ}, 13.31^{\circ}, 16.05^{\circ}, 16.45^{\circ}, 18.57^{\circ}, 20.01^{\circ}$, $21.52^{\circ}, 21.74^{\circ}$, and $23.8^{\circ}$ with increased intensity as compared to control. The sharp peaks in XRD diffractogram of both control and treated samples depicted the crystalline nature of TPP. The increase in intensity of XRD peaks after biofield treatment might be attributed to enhanced 
crystallinity of treated TPP as compared to control. It is presumed that biofield energy may be absorbed by the treated TPP molecules and lead to the formation of long-range symmetrical crystalline phase as compared to control sample. The crystallite size was calculated using Scherrer formula and the results are shown in Figure 2. The crystallite size of control TPP was found as $98.48 \mathrm{~nm}$ that was decreased to $92.44 \mathrm{~nm}$ in treated sample. The result showed about $6.13 \%$ decrease in crystallite size in treated sample as compared to control. It was reported that increase in internal micro strain leads to decrease the corresponding crystallite size of the material [23]. Moreover, Zhang et al. reported that enhanced strain and increase atomic displacement from their ideal positions caused to reduction in crystallite size [24]. Hence, it is assumed that biofield treatment might induce the internal strain in TPP. This might be the responsible for decrease in crystallite size of the treated TPP as compared to control. The effect of biofield treatment on crystallite size was also reported previously [25].

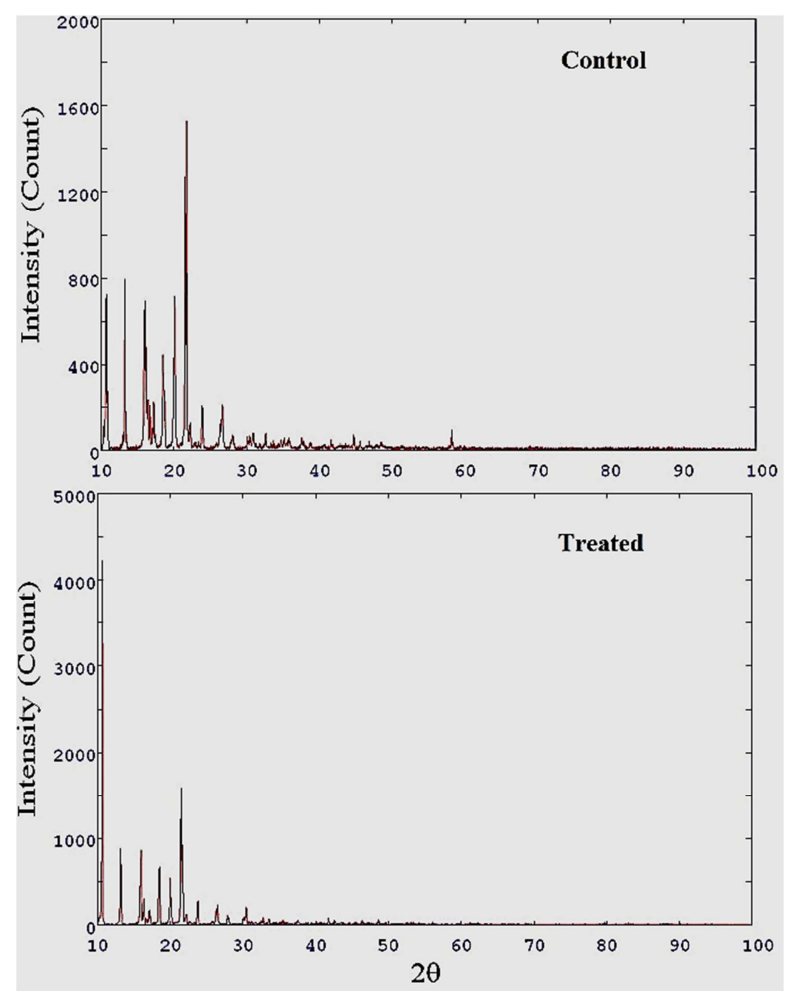

Figure 1. XRD diffractograms of triphenyl phosphate.

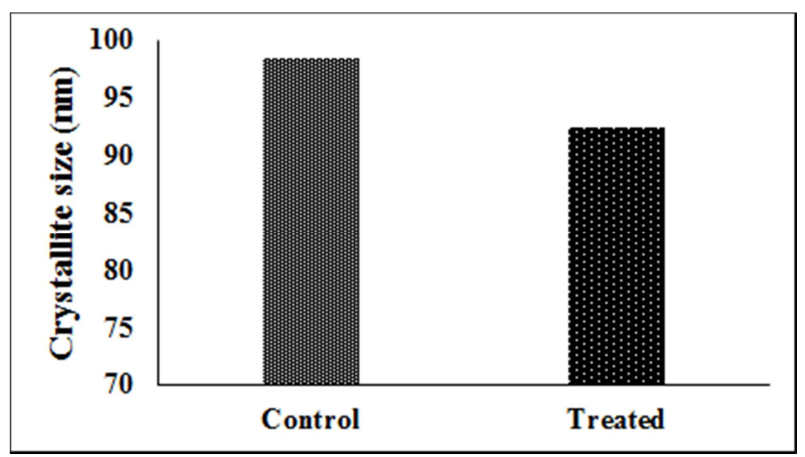

Figure 2. Crystallite size of control and treated triphenyl phosphate.

\subsection{DSC Analysis}

DSC analysis was carried out to determine the melting temperature and latent heat of fusion $(\Delta \mathrm{H})$ of control and treated TPP samples. In solid materials, substantial amount of interaction force exists in atomic bonds that hold the atoms at their positions. $\Delta \mathrm{H}$ is the energy required to overcome the interaction force of phase change i.e. solid into liquid. DSC thermogram (Figure 3) of TPP showed the melting temperature at $51.96^{\circ} \mathrm{C}$ in control and $52.74^{\circ} \mathrm{C}$ in treated sample (Table 1). The result showed about $1.5 \%$ increase in melting temperature in treated sample of TPP as compared to control. The melting temperature of control TPP was well supported by literature data [2]. Likewise, the DSC thermogram exhibited the latent heat of fusion i.e. $47.24 \mathrm{~J} / \mathrm{g}$ in control and $78.58 \mathrm{~J} / \mathrm{g}$ in treated sample of TPP. The result depicted about $66.34 \%$ increase in latent heat of fusion of treated sample as compared to control.

It may be due to increase in intermolecular force in treated TPP as compared to control. Due to which, treated TPP sample probably required higher latent heat of fusion to change the phase from solid to gas as compared to control. Previously, our group has reported that biofield treatment caused alteration in latent heat of fusion in lead and tin powders [6]. Therefore, it is assumed that biofield treatment might alter the intermolecular interaction of treated TPP that may lead to change in latent heat of fusion.
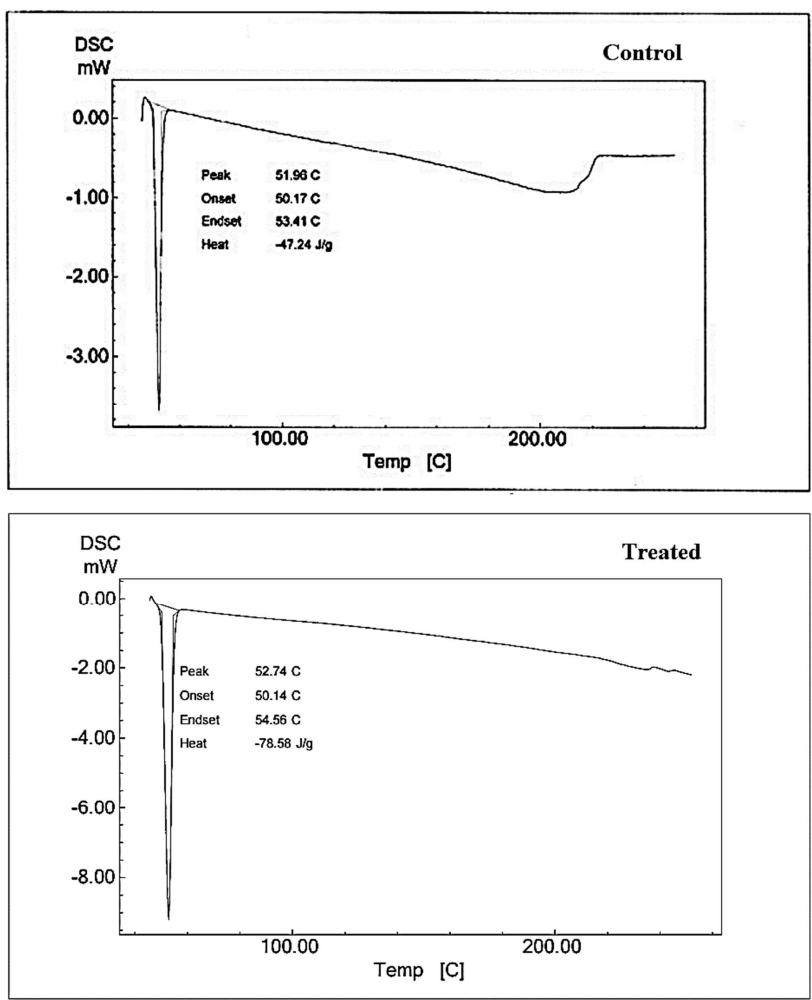

Figure 3. DSC thermograms of control and treated triphenyl phosphate.

\subsection{Thermogravimetric Analysis (TGA)/Derivative Thermogravimetry (DTG) Analysis}

The TGA and DTG thermogram of control and treated 
samples of TPP are shown in Figure 4 and data are reported in Table 1. TGA thermogram of control TPP exhibited the onset temperature around $243^{\circ} \mathrm{C}$, while end-set temperature was observed at $311.5^{\circ} \mathrm{C}$ with $66.79 \%$ weight loss. However, the treated TPP started losing weight around $267^{\circ} \mathrm{C}$ and endset was observed at $310^{\circ} \mathrm{C}$ with $47.96 \%$ weight loss (Figure 4). The result showed increase in onset temperature of treated TPP by $9.88 \%$ as compared to control. This suggests the increased thermal stability of treated TPP with respect to control. Moreover, DTG thermogram exhibited the maximum thermal decomposition temperature $\left(\mathrm{T}_{\max }\right)$ at $273.39^{\circ} \mathrm{C}$ in control sample and at $284.31^{\circ} \mathrm{C}$ in treated sample of TPP.
The result suggested about $3.99 \%$ increase in $\mathrm{T}_{\max }$ of treated sample with respect to control. The increase in $T_{\max }$ of treated sample might be correlated with increased thermal stability of treated TPP as compared to control.

Table 1. Thermal analysis of control and treated samples of triphenyl phosphate.

\begin{tabular}{llll}
\hline S. No. & Parameter & Control & Treated \\
\hline 1 & Latent heat of fusion $(\mathrm{J} / \mathrm{g})$ & 47.24 & 78.58 \\
2 & Melting point $\left({ }^{\circ} \mathrm{C}\right)$ & 51.96 & 52.74 \\
3 & Onset temperature $\left({ }^{\circ} \mathrm{C}\right)$ & 243.00 & 267.00 \\
4 & $\mathrm{~T}_{\max }\left({ }^{\circ} \mathrm{C}\right)$ & 316.29 & 312.21 \\
\hline
\end{tabular}

$\mathrm{T}_{\max }$ : temperature at maximum weight loss occurs
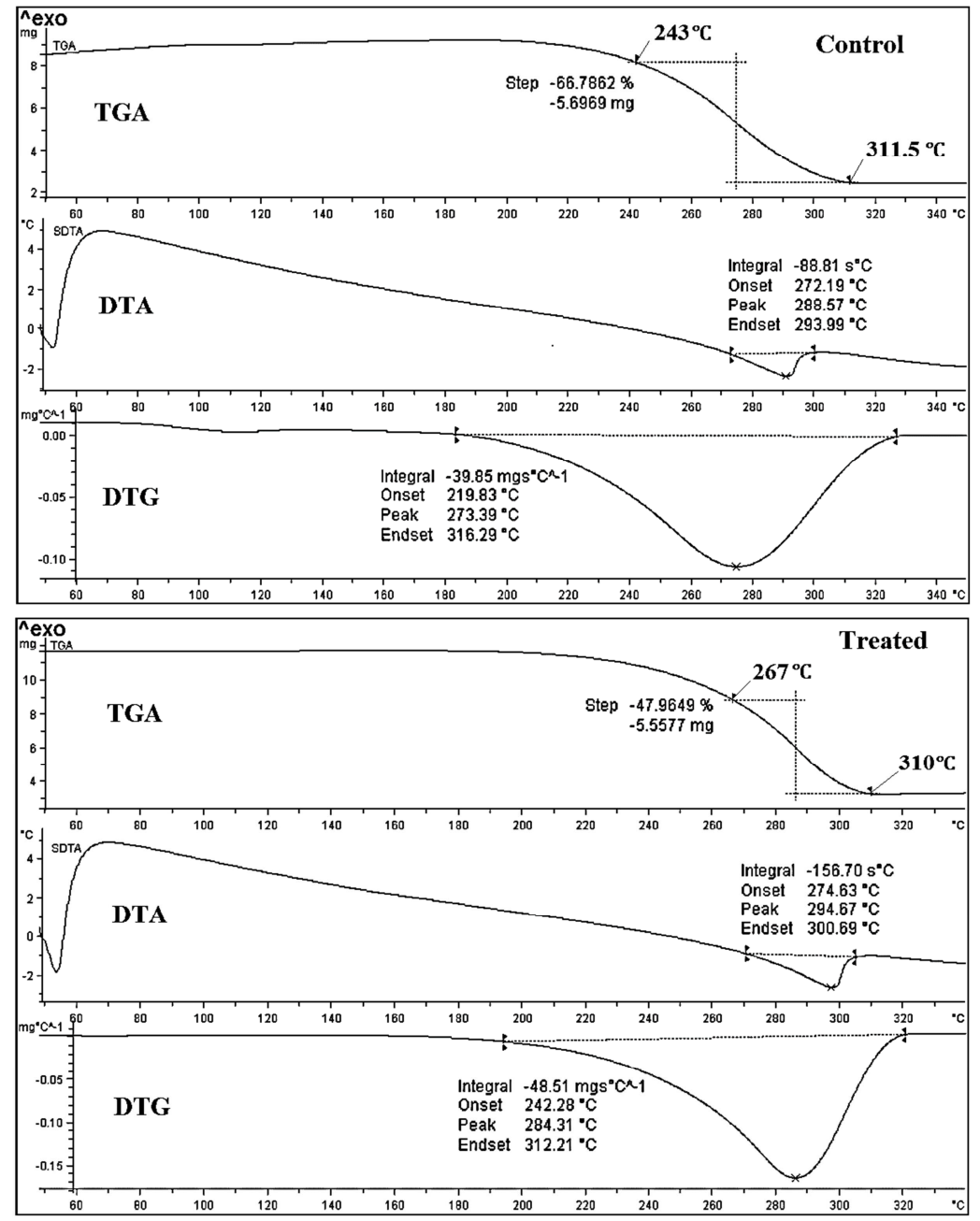

Figure 4. TGA thermograms of control and treated triphenyl phosphate.

Table 2. FT-IR Spectral analysis of triphenyl phosphate.

\begin{tabular}{|c|c|c|c|}
\hline \multicolumn{3}{|c|}{ Wave number $\left(\mathrm{cm}^{-1}\right)$} & \multirow{2}{*}{ Frequency assigned } \\
\hline Control & T1 & T2 & \\
\hline 3059 & 3059 & 3061 & C-H stretching \\
\hline $1456-1587$ & $1454-1589$ & $1456-1589$ & $\mathrm{C}=\mathrm{C}$ stretching \\
\hline 1294 & 1294 & 1292 & $\mathrm{P}=\mathrm{O}$ stretching \\
\hline $1163-1176$ & $1163-1176$ & 1166-1197 & $\mathrm{C}-\mathrm{H}$ in plane deformation \\
\hline $972-1008$ & $970-1008$ & $966-1006$ & P-O stretching \\
\hline $692-786$ & $690-786$ & $690-786$ & $\begin{array}{l}\mathrm{C}-\mathrm{H} \text { out of plane } \\
\text { deformation }\end{array}$ \\
\hline
\end{tabular}

\subsection{FT-IR Spectroscopic Analysis}

The recorded FT-IR spectra of control and treated samples (Figure 5) were analyzed based on theoretically predicted wavenumber and presented in Table 2. The chemical structure of TPP consists with three phenyl groups attached with a phosphorus with the ester linkage. Therefore, FT-IR spectra of TPP should consist with vibrational peaks mainly due to $\mathrm{C}-\mathrm{H}, \mathrm{C}=\mathrm{C}, \mathrm{P}=\mathrm{O}$ and $\mathrm{P}-\mathrm{O}$ groups. The $\mathrm{C}-\mathrm{H}$ stretching was assigned to peak appeared at $3059 \mathrm{~cm}^{-1}$ in control and 
treated (T1) samples, however in T2 sample it was appeared at $3061 \mathrm{~cm}^{-1}$. The $\mathrm{C}=\mathrm{C}$ stretching of phenyl ring carbon was assigned to vibrational peak observed at $1456-1587 \mathrm{~cm}^{-1}$ in control, $1454-1589 \mathrm{~cm}^{-1}$ in $\mathrm{T} 1$, and $1456-1589 \mathrm{~cm}^{-1}$ in $\mathrm{T} 2$ sample of TPP. The $\mathrm{P}=\mathrm{O}$ stretching peak was assigned at $1294 \mathrm{~cm}^{-1}$ in control and T1 sample and $1292 \mathrm{~cm}^{-1}$ in T2 sample of TPP. The C-H in-plane deformation was attributed to vibrational peaks observed at $1163-1176 \mathrm{~cm}^{-1}$ in control and T1 sample; however, it was slightly shifted to higher frequency region i.e. at $1166-1197 \mathrm{~cm}^{-1}$ in T2 sample of TPP. In addition, the P-O stretching peaks were assigned at 972-
$1008 \mathrm{~cm}^{-1}$ in control, $970-1008 \mathrm{~cm}^{-1}$ in $\mathrm{T} 1$ sample, and 966$1006 \mathrm{~cm}^{-1}$ in T2 sample of TPP. The C-H out of plane deformation peaks were assigned at $692-786 \mathrm{~cm}^{-1}$ in control and $690-786 \mathrm{~cm}^{-1}$ in T1 and T2 samples of TPP. Overall, the FT-IR spectrum of TPP was well supported with the literature data [26]. The FT-IR result suggested that the biofield treatment did not show the alteration in the wavenumber of any bond in treated TPP as compared to control. Based on this, it can be concluded that biofield treatment did not affect the dipole moment and force constant of TPP.

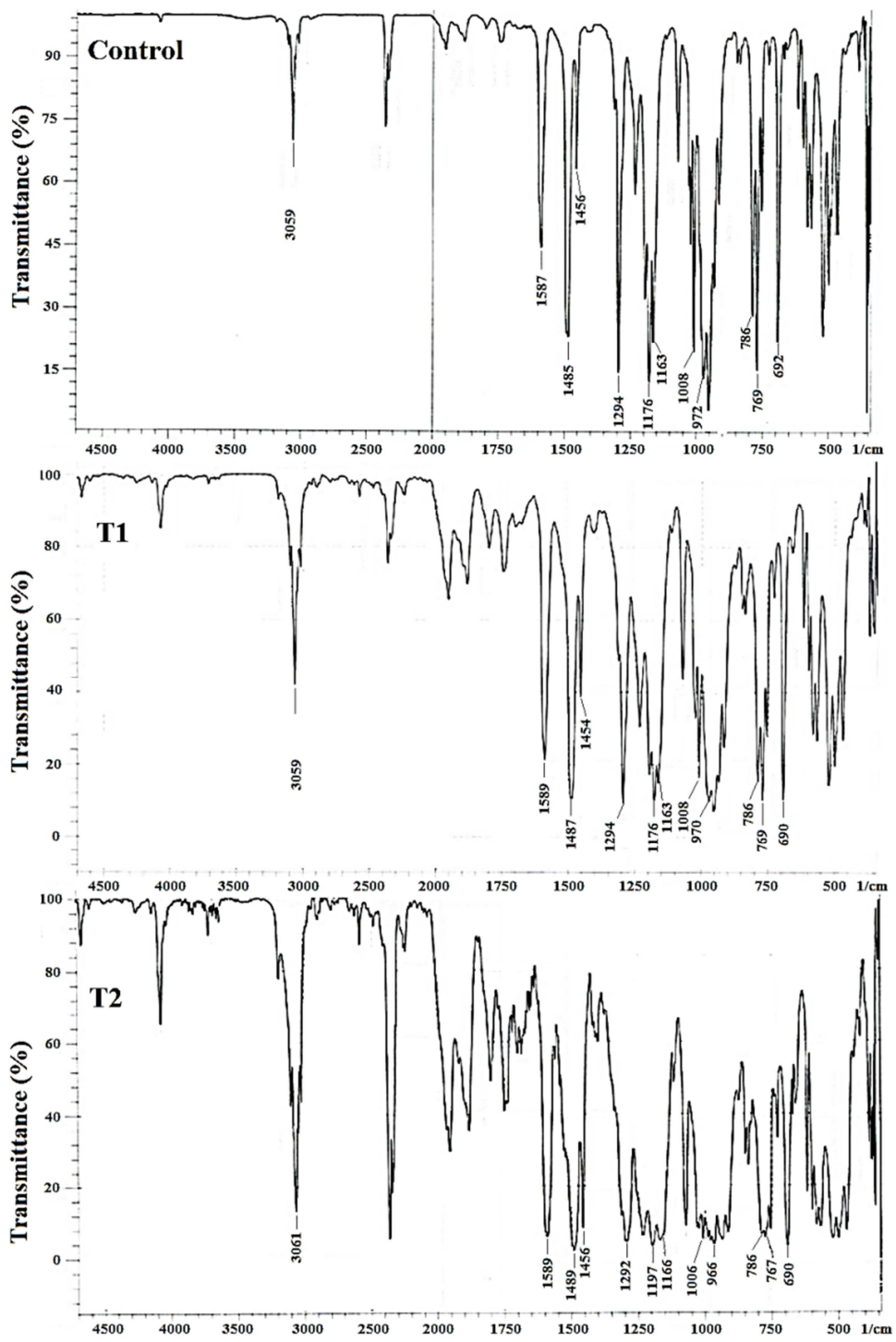

Figure 5. FT-IR spectra of control and treated (T1 and T2) triphenyl phosphate.

\subsection{UV-Vis Spectroscopy}

UV spectrum of control TPP showed absorbance maxima $\left(\lambda_{\max }\right)$ at $204.8,255.4$ and $260.4 \mathrm{~nm}$. Similar pattern of $\lambda_{\max }$ was also observed in both the treated samples (T1 and T2) i.e. at 205.6, 255.6, and $260.6 \mathrm{~nm}$ in $\mathrm{T} 1$ and 205.0, 254.0, and $260.0 \mathrm{~nm}$ in T2. Overall, the UV spectral analysis suggests that biofield treatment did not cause any significant alterations in the $\lambda_{\max }$ of treated TPP sample with respect to control. Altogether, the UV and FT-IR result, suggest that biofield treatment did not alter the structural properties of TPP with respect to control.

\section{Conclusion}

In conclusion, the XRD diffractogram of biofield treated TPP showed the alteration in intensity of XRD peaks and 
decreased crystallite size $(6.13 \%)$ as compared to control. The thermal analysis (DSC, TGA/DTG) showed a slight increase in melting temperature and $\mathrm{T}_{\max }$. However, the latent heat of fusion was significantly increased $(66.34 \%)$ in treated sample as compared to control. The spectroscopic analysis (FT-IR and UV-Vis) showed that biofield treatment did not affect the structural properties of treated sample as compared to control.

Based on XRD, DSC, TGA/DTG analysis, it is concluded that biofield treatment has the impact on physicochemical characteristics of treated TPP with respect to control. The increase in latent heat of fusion, reduction in \% weight loss, and increase in $T_{\max }$ of treated TPP suggests the increase in thermal stability as compared to control, which could be beneficial for it application in thermal safety of lithium-ion batteries.

\section{Acknowledgement}

The authors would like to acknowledge the whole team of MGV pharmacy college, Nashik for providing the instrumental facility. We would also like to thank Trivedi Science $^{\mathrm{TM}}$, Trivedi Master Wellness ${ }^{\mathrm{TM}}$ and Trivedi Testimonials for their consistent support during the work.

\section{References}

[1] Quin LD (2000) A guide to organophosphorus chemistry. John Wiley \& Sons.

[2] van der Veen I, de Boer J (2012) Phosphorus flame retardants: Properties, production, environmental occurrence, toxicity and analysis. Chemosphere 88: 1119-1153.

[3] Shim EG, Nam TH, Kim JG, Kim HS, Moon SI (2007) Electrochemical performance of lithium-ion batteries with triphenylphosphate as a flame-retardant additive. J. Power Sources 172: 912-924.

[4] Pawlowski KH, Schartel B (2007) Flame retardancy mechanisms of triphenyl phosphate, resorcinol bis(diphenyl phosphate) and bisphenol A bis(diphenyl phosphate) in polycarbonate/acrylonitrile-butadiene-styrene blends. Polym Int 56: 1404-1414.

[5] Trivedi MK, Patil S, Tallapragada RMR (2015) Effect of biofield treatment on the physical and thermal characteristics of aluminium powders. Ind Eng Manage 4: 151.

[6] Trivedi MK, Patil S, Tallapragada RM (2013) Effect of bio field treatment on the physical and thermal characteristics of silicon, tin and lead powders. J Material Sci Eng 2: 125.

[7] Trivedi MK, Patil S, Tallapragada RM (2013) Effect of biofield treatment on the physical and thermal characteristics of vanadium pentoxide powders. J Material Sci Eng S11: 001.

[8] Trivedi MK, Nayak G, Patil S, Tallapragada RM, Latiyal O (2015) Studies of the atomic and crystalline characteristics of ceramic oxide nano powders after biofield treatment. Ind Eng Manage 4: 161 .

[9] Trivedi MK, Patil S, Shettigar H, Bairwa K, Jana S (2015) Effect of biofield treatment on spectral properties of paracetamol and piroxicam. Chem Sci J 6: 98.
[10] Trivedi MK, Patil S, Shettigar H, Bairwa K, Jana S (2015) Spectroscopic characterization of chloramphenicol and tetracycline: An impact of biofield. Pharm Anal Acta 6: 395.

[11] Richard M (2003). The basics of chemistry. Westport, Conn, Greenwood Press.

[12] Maxwell JC (1865) A dynamical theory of the electromagnetic field. Phil Trans R Soc Lond 155: 459-512.

[13] Rubik B (2002) The biofield hypothesis: Its biophysical basis and role in medicine. J Altern Complement Med 8: 703-717.

[14] Prakash S, Chowdhury AR, Gupta A (2015) Monitoring the human health by measuring the biofield "aura": An overview. Int J App Eng Res 10: 27637-27641.

[15] Shinde V, Sances F, Patil S, Spence A (2012) Impact of biofield treatment on growth and yield of lettuce and tomato. Aust J Basic Appl Sci 6: 100-105.

[16] Sances F, Flora E, Patil S, Spence A, Shinde V (2013) Impact of biofield treatment on ginseng and organic blueberry yield. Agrivita J Agric Sci 35.

[17] Nayak G, Altekar N (2015) Effect of biofield treatment on plant growth and adaptation. J Environ Health Sci 1: 1-9.

[18] Trivedi MK, Bhardwaj Y, Patil S, Shettigar H, Bulbule, A (2009) Impact of an external energy on Enterococcus faecalis [ATCC-51299] in relation to antibiotic susceptibility and biochemical reactions-an experimental study. J Accord Integr Med 5: 119-130.

[19] Trivedi MK, Patil S (2008) Impact of an external energy on Staphylococcus epidermis [ATCC-13518] in relation to antibiotic susceptibility and biochemical reactions-an experimental study. J Accord Integr Med 4: 230-235.

[20] Trivedi MK, Patil S (2008) Impact of an external energy on Yersinia enterocolitica [ATCC-23715] in relation to antibiotic susceptibility and biochemical reactions: An experimental study. Internet J Alternat Med 6.

[21] Patterson AL (1939) The Scherrer formula for X-ray particle size determination. Phys Rev 56: 978-982.

[22] Pavia DL, Lampman GM, Kriz GS (2001) Introduction to spectroscopy. (3rdedn), Thomson Learning, Singapore.

[23] Paiva-Santos CO, Gouveia H, Las WC, Varela JA (1999) Gauss-Lorentz size-strain broadening and cell parameters analysis of $\mathrm{Mn}$ doped $\mathrm{SnO}_{2}$ prepared by organic route. Mat Struct 6: 111-115.

[24] Zhang K, Alexandrov IV, Kilmametov AR, Valiev RZ, Lu K (1997) The crystallite-size dependence of structural parameters in pure ultrafine-grained copper. J Phys D Appl Phys 30: 3008-3015.

[25] Trivedi MK, Nayak G, Tallapragada RM, Patil S, Latiyal O, et al. (2015) Effect of biofield treatment on structural and morphological properties of silicon carbide. J Powder Metall Min 4:132.

[26] Clark RJH, Flint CD, Hempleman AJ (1987) FTIR and Raman spectra of triphenylphosphine, triphenylarsine, triphenylstibine, and dibenzylsulphide. Spectrochim Acta, Part A 43: 805-816. 